\title{
PENGOLAHAN DATA KUISIONER PENGGUNA WEBSITE MENGGUNAKAN METODE PENGURUTAN QUICKSORT GUNA TERCAPAINYA TUJUAN HUMAN COMPUTER INTERACTION
}

\author{
Dwi Nugraheny \\ Program Studi Teknik Informatika \\ Sekolah Tinggi Teknologi Adisutjipto, Yogyakarta \\ Email: henynug@gmail.com
}

\begin{abstract}
ABSTRAK
Website adalah sebuah cara untuk menampilkan diri di Internet. Dapat diibaratkan Website adalah sebuah tempat di Internet, siapa saja di dunia ini dapat mengunjunginya, kapan saja seseorang dapat mengetahui tentang diri orang lain, memberi pertanyaan pada seseorang, serta memberikan masukkan atau bahkan mengetahui dan membeli suatu produk. Pada penelitian ini akan mengelola kuisioner pengguna website di STTA menggunakan metode pengurutan quicksort guna mengetahui apakah website yang sudah ada memenuhi tujuan dari Human Computer Interaction (HCI) berdasarkan beberapa variabel dari user interface dan user experience. Pengolahan data pengguna Website STTA menggunakan metode quicksort diperoleh hasil bahwa Usability, Quality of Information (kualitas informasi) dan Classic Aesthetics masuk kategori “baik", sedangkan Content, Pleasure, Expressive Aesthetics masuk kategori “cukup". Hal tersebut mengindikasikan bahwa tujuan Human Computer Interaction (HCI) yaitu Usability, Effective dan Efficient masuk kriteria "baik". Tetapi dari segi Appeal masuk kategori "cukup", sehingga masih perlu dilakukan evaluasi guna perbaikan dan peningkatan website yang sudah ada.
\end{abstract}

Kata kunci: quicksort, human computer interaction, website.

\begin{abstract}
Websites are a way to present themselves on the Internet. Can be likened Website is a place on the Internet, anyone in this world can visit it, anytime someone can know about other people, give a question to someone, and give enter or even know and buy a product. In this research will manage the questionnaire of website users in STTA using quicksort sorting method to find out if the existing website meets the purpose of Human Computer Interaction (HCI) based on some variables of user interface and user experience. User data processing STTA website using quicksort method obtained result that Usability, Quality of Information and Classic Aesthetics are categorized as "good", while Content, Pleasure, Expressive Aesthetics is categorized as "enough". It indicates that the purpose of Human Computer Interaction (HCI) that is Usability, Effective and Efficient enter the criterion "good". But in terms of Appeal into the category of "enough", so still need to be evaluated for repair and improvement of existing websites.
\end{abstract}

Keywords: quicksort, human computer interaction, website.

\section{PENDAHULUAN}

Metoda quicksort juga sering disebut dengan metoda partition exchange sort. Metoda ini diperkenalkan oleh C.A.R. Hoare. Untuk mempertinggi efektifitasnya, dalam metoda ini jarak kedua elemen yang akan ditukarkan nilainya ditentukan cukup besar [4]. Sangat memungkinkan untuk menulis algoritma yang lebih cepat untuk beberapa kasus khusus, namun untuk kasus umum, sampai saat ini tidak ada yang lebih cepat dibandingkan metoda algoritma quicksort. Walaupun begitu metoda algoritma quicksort tidak selalu merupakan pilihan yang terbaik. Metoda ini dilakukan secara rekursif yang berarti jika dilakukan untuk tabel yang berukuran sangat besar, walaupun cepat, dapat menghabiskan memori yang besar pula. Quicksort adalah algoritma sorting yang berdasarkan pembandingan dengan metoda divideand-conqueror. Quicksort adalah metode pengurutan yang ideal beradaptasi untuk pengurutan dalam penyimpanan yang random.

Website adalah sebuah cara untuk menampilkan diri di Internet, dapat diibaratkan Website adalah sebuah tempat di internet, siapa saja di dunia ini dapat mengunjunginya, kapan saja seseorang dapat mengetahui tentang diri orang lain, memberi pertanyaan pada seseorang, serta memberikan masukkan atau bahkan mengetahui dan membeli suatu produk. Desain User Interface dan User Experience yang baik pada sebuah website akan membuat pengunjung ingin berlama-lama pada situs web tersebut. Tetapi sebaliknya, 
sebuah desain User Interface dan User Experience yang buruk sebuah website membuat pengunjung pergi meninggalkan situs web tersebut.

Website di Sekolah Tinggi Teknologi Adisutjipto (STTA) dibangun sejak tahun 2005 dengan nama situs STTA.ac.id. Kemudian tahun 2008 dilakukan renovasi pada konten layanan akademik dan pada konten e-learning. Tahun 2014 dilakukan renovasi pada bagian desainnya dan penambahan konten layanan berita. Seiring dilakukan renovasi dan penambahan konten serta renovasi desain web pada beberapa periode tersebut, apakah user interface pada web STTA telah tercapai ?. Apakah berdasarkan user experience, unsur variabel usability, content, pleasure, classic aesthetics, expressive aesthetics serta quality of information (kualitas informasi) web STTA telah tercapai ?.

Berdasarkan uraian di atas, pada penelitian ini akan dibuat aplikasi untuk mengimplementasikan pengolahan data kuisioner dari para pengguna website STTA menggunakan metode quicksort untuk mengetahui variabel-variabel manakah dari tujuan Human Computer Interaction (HCI) dapat tercapai berdasarkan User Interface dan User Experience sehingga nantinya dapat digunakan sebagai bahan evaluasi pembenahan website yang sudah ada menjadi lebih baik lagi.

\section{METODOLOGI PENELITIAN}

Metodologi dalam penelitian ini diantaranya dengan melihat dan memahami pustaka-pustaka yang sudah ada, mempelajari teori-teori yang mendukung, menggunakan data-data pertanyaan kuisioner secara sekunder yaitu menggunakan data pertanyaan dari beberapa variabel pada penelitian sebelumnnya yang diolah menggunakan pengolahan data statistik, data pertanyaan yang telah ada diimplementasikan menggunakan metode quicksort untuk mendapatkan kriteria variabel tertinggi guna tercapainya tujuan Human Computer Interaction (HCI).

\subsection{Tinjauan Pustaka}

Pada penelitian [11] tentang “User Interface Design”, menjelaskan bahwa User interface merupakan unsur yang paling penting dari sebuah sistem berbasis komputer atau produk. Jika antarmuka dirancang sederhana, kemampuan pengguna untuk memanfaatkan kekuatan komputasi dari aplikasi mungkin sangat terhalang. Bahkan, antarmuka yang lemah dapat menyebabkan aplikasi lain yang dirancang dengan baik dan kokoh dilaksanakan dapat juga gagal. Tiga prinsip penting memandu desain user interface yang efektif: (1) menempatkan pengguna dalam kontrol, (2) mengurangi beban memori pengguna, dan (3) membuat antarmuka yang konsisten. Untuk mencapai sebuah antarmuka yang mematuhi prinsip tersebut, proses desain terorganisir harus dilakukan. Desain user interface dimulai dengan identifikasi pengguna, tugas, dan persyaratan lingkungan. Analisis tugas adalah kegiatan desain yang mendefinisikan tugas dan tindakan pengguna baik menggunakan pendekatan elaboratif atau berorientasi objek. Setelah tugas telah diidentifikasi, skenario pengguna yang dibuat dan dianalisis untuk menentukan satu set antarmuka objek dan tindakan. Hal ini memberikan dasar untuk pembuatan layar tata letak yang menggambarkan desain grafis dan penempatan ikon, definisi layar deskriptif teks, spesifikasi dan sertifikasi untuk jendela, dan spesifikasi dari item menu besar dan kecil, masalah desain seperti waktu respon, perintah dan struktur aksi, penanganan error. User interface adalah jendela ke dalam perangkat lunak. Jika "Jendela" yang tercoreng, bergelombang, atau rusak, pengguna dapat menolak sistem berbasis komputer dinyatakan kuat.

Pada penelitian [6] tentang Analisis "User Interface dan User Experience pada Website Sekolah Tinggi Teknologi Adisutjipto (STTA) Yogyakarta", menjelaskan bahwa hasil uji statistik dari para pengguna website STTA memiliki Usability dan Quality of Information (kualitas informasi) dengan kategori "baik", serta memiliki Content, Pleasure, Classic Aesthetics, Expressive Aesthetics yang "cukup"

Pada penelitian [8] dalam tentang "Analisis Perbandingan Algoritma Metode Pengurutan Quicksort, Metode Pengurutan Selectionsort Dan Metode Pengurutan Heapsort" bahwa algoritma pengurutan tersebut dari segi waktu Selectionsort yang lebih unggul dibanding dengan algoritma pengurutan Quicksort, sedangkan Heapsort berbeda jauh dengan kedua algoritma tersebut. Memori yang dipakai pada ketiga algoritma tersebut yang paling besar yaitu pengurutan Heapsort sedangkan pengurutan Selection dan pengurutan Quicksort tidak berbeda jauh.

Pada penelitian [3] tentang "Tinjauan Human Computer Interaction (Hci) Terhadap Aplikasi Penjadwalan Sekolah". Pada pembahasan ini difokuskan pada tampilan (user interface) dari aplikasi perangkat lunak penjadwalan guru apakah sudah dapat memenuhi beberapa aspek kriteria sebuah tampilan yang baik, sehingga interface yang dihasilkan dapat dengan mudah dipelajari dan nyaman digunakan (user friendly), hasil dari pembahasan ini diharapkan menjadi acuan dan rujukan untuk menentukan tahap mengevaluasi interface selanjutnya. 


\subsection{Metoda Quicksort}

Metoda quicksort juga sering disebut dengan metoda partition exchange sort. Metoda ini diperkenalkan oleh C.A.R. Hoare. Untuk mempertinggi efektifitasnya, dalam metoda ini jarak kedua elemen yang akan ditukarkan nilainya ditentukan cukup besar [4]. Sangat memungkinkan untuk menulis algoritma yang lebih cepat untuk beberapa kasus khusus, namun untuk kasus umum, sampai saat ini tidak ada yang lebih cepat dibandingkan metoda algoritma quicksort. Walaupun begitu metoda algoritma quicksort tidak selalu merupakan pilihan yang terbaik. Metoda ini dilakukan secara rekursif yang berarti jika dilakukan untuk tabel yang berukuran sangat besar, walaupun cepat, dapat menghabiskan memori yang besar pula. Quicksort adalah algoritma sorting yang berdasarkan pembandingan dengan metoda divideand-conqueror. Quicksort adalah metode pengurutan yang ideal beradaptasi untuk pengurutan dalam penyimpanan yang random.

Quicksort adalah sebuah algoritma sortir dari model Divide and Conquer yaitu dengan cara mereduksi tahap demi tahap sehingga menjadi 2 bagian yang lebih kecil. I

a. Mengidentifikasi key pada indeks pertama dalam list.

b. List dipartisi menjadi 2 bagian dimana list yang sebelah kiri adalah kumpulan dari key-key yang lebih kecil dari key pada indeks pertama dan list yang disebelah kanan adalah kumpulan dari keykey yang lebih besar dari key pada indeks pertama.

Quicksort disebut juga dengan partition exchange sort, karena konsepnya membuat partisi-partisi, dan sort dilakukan per partisi. Dalam algoritma quicksort, pemilihan pivot adalah hal yang menentukan apakah algoritma quicksort tersebut akan memberikan performa terbaik atau terburuk. Quicksort lebih unggul dari algoritma-algoritma pengurutan data yang ada karena:

a. Quicksort memiliki performa yang baik di berbagai kondisi.

b. Quicksort lebih sederhana dibandingkan dengan algoritma pengurutan data yang lain.

c. Analisa matematis dan analisa bukti empiris menunjukkan bahwa quicksort bisa diharapkan bekerja dua kali lebih cepat dibandingkan metode lain yang serupa.

d. Quicksort cukup sederhana untuk dipelajari para programmer yang baru mempelajari pengurutan data.

Secara sederhana metode Quicksort Rekursif [4] dituliskan sebagai berikut:

Procedure QUICKSORT (var A: Larik; Awal, Akhir: integer);

Var I,J : integer;

Begin

If Awal < Akhir then

Begin

ATUR;

QUICKSORT (A, Awal, J-1);

QUICKSORT (A, J+1, Akhir)

End

End;

Teks Algoritma Quicksort [4] adalah sebagai berikut:

Algoritma ATUR

Langkah $1 \quad$ Tentukan: I - Awal + 1

Langkah 2 (Bergerak dari kiri ke kanan)

Tambah nilai I dengan 1 selama A $[\mathrm{I}]<$ A [Awal]

Langkah 3

(Bergerak dari kanan ke kiri)

Kurangi nilai I dengan 1 selama $\mathrm{A}[\mathrm{J}]>\mathrm{A}[$ Awal]

Langkah 4

Kerjakan langkah 5 sampai 7 selama I $<$ J

Langkah 5

Tukarkan nilai $\mathrm{A}[\mathrm{I}]$ dengan $\mathrm{A}[\mathrm{J}]$

Langkah 6

(Bergerak dari kiri ke kanan)

Tambah Nilai I dengan 1 selama A[I] < A [Awal]

Langkah 7 (Bergerak dari kanan ke kiri)

Kurangi nilai I dengan 1 selama $\mathrm{A}[\mathrm{J}]>\mathrm{A}[$ Awal $]$

Langkah 8

Langkah 9

Tukarkan nilai $\mathrm{A}[\mathrm{I}]$ dengan $\mathrm{A}[\mathrm{J}]$

Selesai

Gambar 1 merupakan ilustrasi metode quicksort dalam pengurutan data-data. 


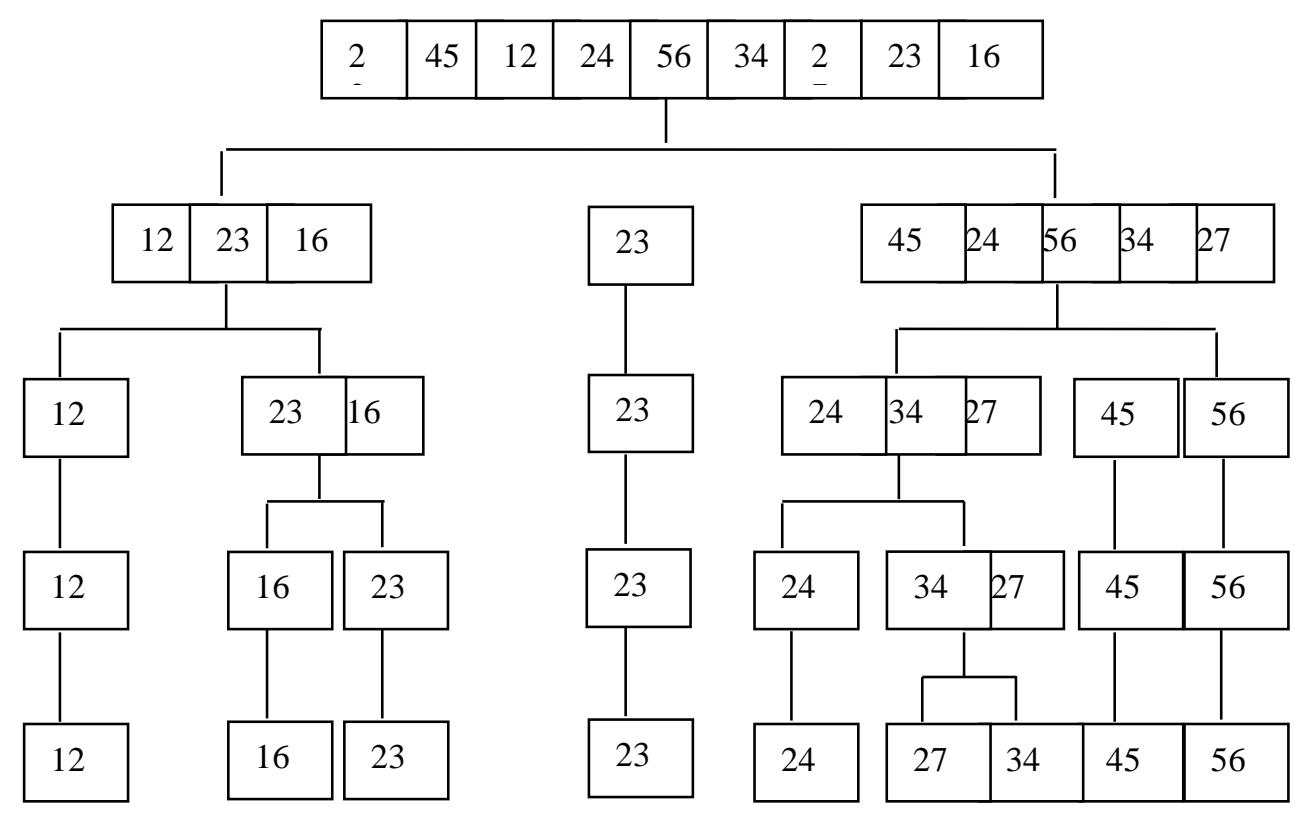

Gambar 1.Ilustrasi Metode Quicksort

(Sumber : Ir. P. Insap Santosa, M.Sc., 2000)

\subsection{Human Computer Interaction (HCI)}

Menurut [2], Human Computer Interaction (Interaksi Manusia Komputer) adalah disiplin ilmu yang berkaitan dengan desain, evaluasi dan implementasi sistem komputer interaktif untuk digunakan manusia dan dengan studi fenomena besar di sekitar mereka. Tujuan dari Human Computer Interaction adalah untuk mengembangkan dan perbaikan pada sisi safety, utility, effective, efficiency, usability, appeal.

a. Safety, berupa keamanan data, perlindungan file dari gangguan, privasi dan keamanan.

b. Utility, adalah jenis layanan apa yang disediakan oleh sistem, misalnya kemampuan sistem untuk mencetak dokumen.

c. Effective, yaitu user mampu untuk mencapai tujuan yang diharapkan dari sistem, misalnya: bagaimana untuk mencetak laporan, bagaimana untuk mendapatkan informasi dari suatu sistem.

d. Efficiency, yaitu ukuran bagaimana user secara cepat dapat menyelesaikan pekerjaan menggunakan sistem sesuai tujuan.

e. Usability, yaitu ukuran kemudahan suatu sistem untuk dapat dipelajari dan digunakan, efektif serta efisien sehingga sikap user menyukai dan puas dengan sistem tersebut [7].

f. Appeal yaitu sistem mempunyai tampilan yang menarik dan sederhana.

Menurut [1], prinsip-prinsip untuk mendukung kegunaan (usability) yaitu:

a. Mudah dipelajari (Learnbility) yaitu kemudahan pengguna baru dapat menggunakan sistem secara efektif.

b. Keluwesan (Flexibility) yaitu banyaknya (berbagai) cara pengguna memperoleh atau menukar sistem informasi.

c. Kehandalan (Robustness) yaitu tingkat dukungan yang diberikan sistem ke user dalam menentukan keberhasilan pencapaian dan penilaian perilaku yang diarahkan sesuai tujuan user.

\subsection{Identifikasi Variabel}

Beberapa variabel yang digunakan terkait tentang user interface dan user experience pada website Sekolah Tinggi Teknologi Adisutjipto (STTA) untuk para responden dalam data-data kuisioner terdiri dari 6 (enam) variabel yaitu: usability, content, pleasure, classic aesthetics, expressive aesthetics serta quality of Information. Variabel-variabel tersebut diidentifikasi berdasarkan beberapa referensi mengenai user interface dan user experience.

a. Usability yaitu ukuran kemudahan suatu sistem untuk dapat dipelajari dan digunakan, luwes, efektif serta efisien sehingga sikap user menyukai dan puas dengan sistem tersebut [7].

b. Content, adalah informasi yang tersedia melalui media atau produk elektronik. Pada dasarnya ada dua jenis web content yaitu teks dan multimedia . 
c. Pleasure, dimaksudkan sistem yang disajikan menarik sehingga pengguna merasa senang menggunakan sistem tersebut berkaitan dengan unsur usability.

d. Classic Aesthetics, merujuk gagasan tradisional yang menekankan pada desain yang tertib dan jelas terhadap tampilan berkaitan dengan bidang ilmu Human Computer Interaction (HCI).

e. Expressive Aesthetics, lebih tertuju pada kreativitas desain dan orisinalitas.

Quality of Information (kualitas Informasi), kualitas dari suatu informasi tergantung dari 3 (tiga) hal yaitu informasi harus akurat (accurate), tepat waktu (timelines) dan relevan (relevance) [9]. Untuk dapat berguna, maka informasi harus didukung oleh tiga pilar yaitu: tepat kepada orangnya (relevance), tepat waktu (timeliness) dan tepat nilainya (accurate) [5].

\subsection{Teknik Pengolahan Data}

Data-data yang telah diperoleh melalui penyebaran kuisioner kemudian diolah menggunakan metode Quicksort guna membahas hasil hipotesa dan menganalisa hasil responden para pengguna website STTA sesuai pertanyaan-pertanyaan yang diajukan pada lembar kuisioner pada sudut pandang User Experience dan User Interface diantaranya melalui beberapa variabel pertanyaan tentang usability, content, pleasure, classic aesthetics, expressive aesthetics serta quality of Information (kualitas informasi). Adapun kriteria jawaban para responden adalah: "Sangat Baik" = 4, "Baik" = 3, "Cukup" =2, "Kurang"=1.

\section{HASIL DAN PEMBAHASAN}

\subsection{Pengolahan Data Menggunakan Metode Quicksort}

Pengolahan data pada penelitian ini menggunakan metode quicksort berdasarkan data-data kuisioner dari para pengguna website yaitu Mahasiswa dan Karyawan sebanyak 106 kuisioner. Kemudian data-data dilakukan pemfilteran dari data-data yang komplit diisi (valid) dan data-data yang tidak komplit atau tidak lengkap diisi (tidak valid). Sehingga hasil pemfilteran data-data hasil kuisioner sejumlah 96 kuisioner yang kemudian diolah menggunakan metode quicksort.

Pada Gambar 2. merupakan tampilan 6 (enam) kategori variabel utama dengan sejumlah masing pertanyaan yang berpengaruh pada user interface dan user experience terhadap website STTA. Ke enam kategori variabel yang diujikan tersebut berurutan sebagai berikut : Usability, Content, Pleasure, Classic Aesthetics, Expressive Aesthetics, Kualitas Informasi (Quality of Information).

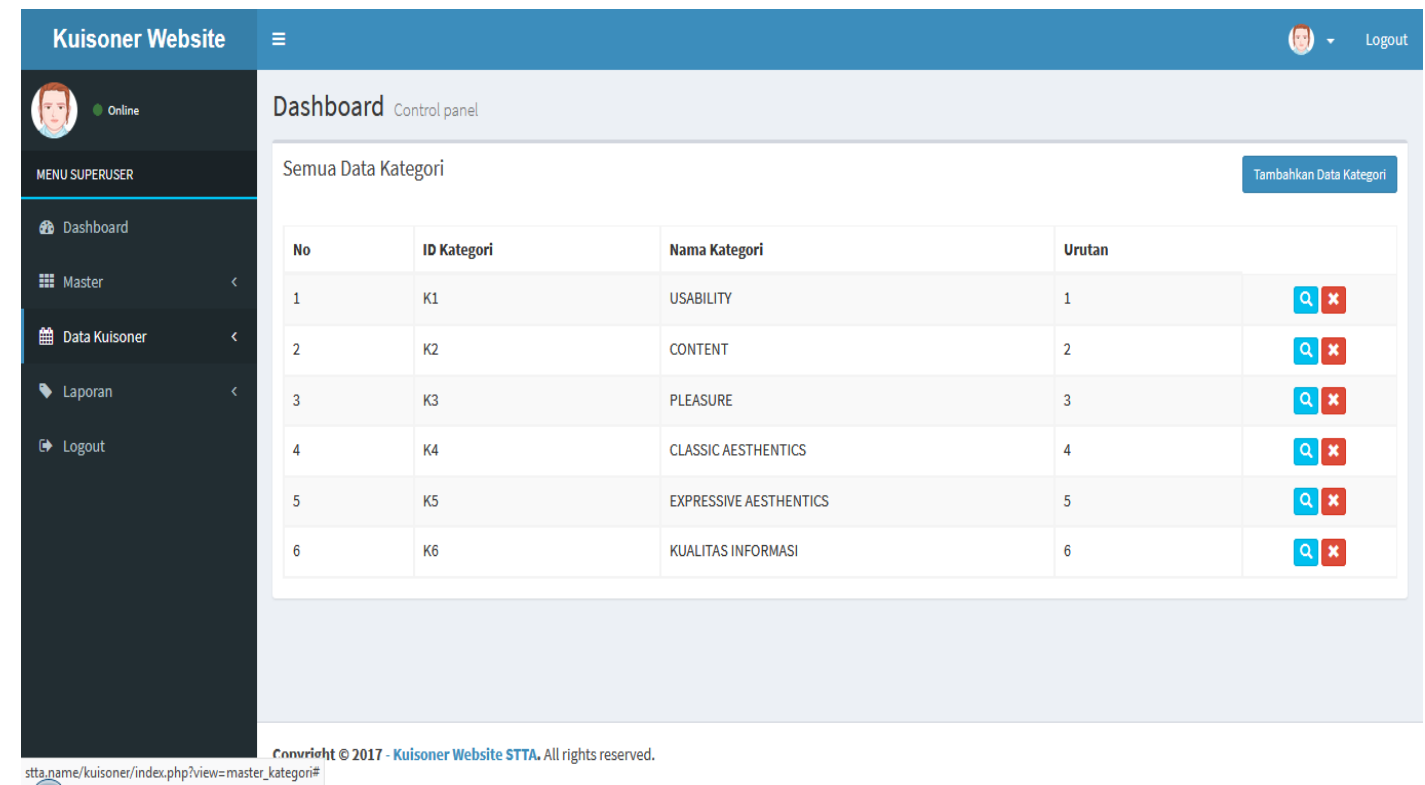

Gambar 2. Tampilan Ke Enam Variabel Yang Diujikan 
Kategori PLEASURE

\begin{tabular}{|l|l|c|c|c|c|}
\hline No & Pertanyaan & Kurang & Cukup & Baik & Sangat Baik \\
\hline 9. & Saya merasa senang saat berinteraksi dengan website & 0 & 0 & 0 & 0 \\
\hline 10. & Website enak dilihat/menarik & 0 & 0 & 0 & 0 \\
\hline 11. & Website memiliki fitur/fitur yang menyenangkan & 0 & 0 & 0 & 0 \\
\hline 12. & Website menimbulkan perasaan positif terhadap pengunjung & 0 & 0 & 0 & 0 \\
\hline
\end{tabular}

\section{Kategori CLASSIC AESTHENTICS}

\begin{tabular}{|c|c|c|c|c|c|}
\hline No & Pertanyaan & Kurang & Cukup & Baik & Sangat Baik \\
\hline 13. & Desain website menampilkan westetika yang baik & 0 & 0 & 0 & 0 \\
\hline 14. & Website memiliki tampilan desain yang menyenangkan & 0 & 0 & 0 & 0 \\
\hline 15. & Website memiliki tampilan desain yang simetris & 0 & 0 & 0 & 0 \\
\hline
\end{tabular}

\section{e $\quad$ Q $P$ D}

\section{Gambar 3. Tampilan Pertanyaan Dari Ke Enam Kategori Variabel}

Pada gambar 3 merupakan tampilan masing-masing pertanyaan dari ke enam kategori variabel dari gambar 2 untuk dijawab para responden pengguna (user) website STTA. Seluruh pertanyaan yang disajikan sejumlah 24 pertanyaan dari ke enam variabel utama.

\begin{tabular}{|c|c|c|c|c|}
\hline 10 & PLEASURE & 10 & Website enak dilihat/menarik & 240 \\
\hline 11 & PLEASURE & 11 & Website memiliki fitur/fitur yang menyenangkan & 236 \\
\hline 12 & PLEASURE & 12 & Website menimbulkan perasaan positif terhadap pengunjung & 254 \\
\hline 13 & CLASSICAESTHENTICS & 13 & Desain website menampilkan westetika yang baik & 270 \\
\hline 14 & CLASSICAESTHENTICS & 14 & Website memiliki tampilan desain yang menyenangkan & 254 \\
\hline 15 & CLASSICAESTHENTICS & 15 & Website memiliki tampilan desain yang simetris & 248 \\
\hline 16 & EXPRESSIVE AESTHENTICS & 16 & Website memiliki tampilan desain yang kreatif & 246 \\
\hline 17 & EXPRESSIVE AESTHENTICS & 17 & Website memiliki tampilan desain yang mengagumkan & 217 \\
\hline 18 & EXPRESSIVE AESTHENTICS & 18 & Website menggunakan special effect (misal : animasi 3D, mottion animation, flash dIl) & 228 \\
\hline 19 & EXPRESSIVE AESTHENTICS & 19 & Website memiliki tampilan desain yang berkelas & 219 \\
\hline 20 & KUALITAS INFORMASI & 20 & Informasi yang disajikan dapat dipercaya & 284 \\
\hline 21 & KUALITAS INFORMASI & 21 & keterhubungan informasi yang dihasilkan sesuai dengan informasi yang ada di organisasi & 270 \\
\hline 22 & KUALITAS INFORMASI & 22 & Ketelitin informasi yang dihasilkan & 264 \\
\hline 23 & KUALITAS INFORMASI & 23 & Kelengkapan informasi yang dihasilkan & 261 \\
\hline \multirow[t]{2}{*}{24} & KUALITAS INFORMASI & 24 & Penyajian informasi yang tepat waktu & 240 \\
\hline & & & oses Pengurutan dengan Metode Quick Sor & \\
\hline
\end{tabular}

Gambar 4. Tampilan Hasil Perhitungan Jawaban Berdasarkan Kriteria Dan Jumlah Pertanyaan Pervariabel 
Gambar 4 merupakan tampilan hasil perhitungan jawaban berdasarkan kriteria dan jumlah pertanyaan pervaribel yang kemudian akan diolah menggunakan metode quicksort.

\section{Detail Pengurutan Dengan Metode Quick Sort}

$281,285,281,271,247,253,251,255,249,240,236,254,270,254,248,246,217,228,219,284,270,264,261,240$ @unsorted $240,219,228,217,247,253,251,246,249,240,236,248,254,270,254,255,271,281,285,284,270,264,261,281 @$ @ pivot 254 $240,219,228,217,247,248,236,246,249,240,251,253,254,270,254,255,271,281,285,284,270,264,261,281 @$ pivot 251 $240,219,228,217,240,246,236,248,249,247,251,253,254,270,254,255,271,281,285,284,270,264,261,281$ @pivot 247 $217,219,228,240,240,246,236,248,249,247,251,253,254,270,254,255,271,281,285,284,270,264,261,281 @$ @pivot 217 $217,219,228,236,240,246,240,248,249,247,251,253,254,270,254,255,271,281,285,284,270,264,261,281 @$ pivot 240 $217,219,228,236,240,246,240,248,249,247,251,253,254,270,254,255,271,281,285,284,270,264,261,281 @$ @pivot 228 $217,219,228,236,240,246,240,248,249,247,251,253,254,270,254,255,271,281,285,284,270,264,261,281 @$ pivot 219 $217,219,228,236,240,246,240,248,249,247,251,253,254,270,254,255,271,281,285,284,270,264,261,281 @$ @ivot 236 $217,219,228,236,240,240,246,248,249,247,251,253,254,270,254,255,271,281,285,284,270,264,261,281 @$ pivot 246 $217,219,228,236,240,240,246,248,247,249,251,253,254,270,254,255,271,281,285,284,270,264,261,281 @$ @pivot 249 $217,219,228,236,240,240,246,247,248,249,251,253,254,270,254,255,271,281,285,284,270,264,261,281 @$ pivot 248 $217,219,228,236,240,240,246,247,248,249,251,253,254,270,254,255,271,281,285,284,270,264,261,281 @$ @pivot 253 $217,219,228,236,240,240,246,247,248,249,251,253,254,270,254,255,271,281,285,284,270,264,261,281 @$ pivot 251 $217,219,228,236,240,240,246,247,248,249,251,253,254,270,254,255,271,281,281,284,270,264,261,285$ @pivot 285 $217,219,228,236,240,240,246,247,248,249,251,253,254,270,254,255,271,261,264,270,284,281,281,285$ @pivot 281 $217,219,228,236,240,240,246,247,248,249,251,253,254,270,254,255,270,261,264,271,284,281,281,285$ @pivot 271 $217,219,228,236,240,240,246,247,248,249,251,253,254,255,254,270,270,261,264,271,284,281,281,285$ @pivot 255 $217,219,228,236,240,240,246,247,248,249,251,253,254,254,255,270,270,261,264,271,284,281,281,285$ @pivot 255 $217,219,228,236,240,240,246,247,248,249,251,253,254,254,255,264,261,270,270,271,284,281,281,285$ @pivot 270 $217,219,228,236,240,240,246,247,248,249,251,253,254,254,255,261,264,270,270,271,284,281,281,285$ @pivot 264 $217,219,228,236,240,240,246,247,248,249,251,253,254,254,255,261,264,270,270,271,284,281,281,285$ @pivot 270 $217,219,228,236,240,240,246,247,248,249,251,253,254,254,255,261,264,270,270,271,281,281,284,285$ @pivot 281 $217,219,228,236,240,240,246,247,248,249,251,253,254,254,255,261,264,270,270,271,281,281,284,285$ @pivot 281 $217,219,228,236,240,240,246,247,248,249,251,253,254,254,255,261,264,270,270,271,281,281,284,285$ @sorted

\section{Gambar 5. Tampilan Nilai-Nilai Hasil Perhitungan Jawaban Pertanyaan Kuisioner Menggunakan} Metode Quicksort

Gambar 5. merupakan hasil skor masing-masing pertanyaan dari 6 (enam) kategori variabel sejumlah 24 pertanyaan dan dijawab sejumlah 96 responden yang valid serta berdasarkan 4 (empat) kriteria yaitu: "Sangat Baik" = 4, "Baik" = 3, "Cukup" = 2, "Kurang"=1. Nilai skor pada gambar 4. tersebut pada baris pertama terlihat masih acak belum terurutkan. Kemudian dilakukan penentuan pivot yang digunakan sebagai poros untuk melakukan perbandingan nilai-nilai skor pada bagian kiri dan bagian kanan pivot. Jika pada nilai skor < pivot, maka nilai skor ditukar ke bagian kiri pivot. Jika pada nilai skor > pivot, maka nilai skor ditukar ke bagian kanan pivot. Proses rekursi dilakukan berulang-ulang sampai nilai skor terurutkan baik secara ascending maupun descending. Berikut ini merupakan koding untuk mencari pivot dalam bentuk nilai-nilai skor dalam proses pengolahan data menggunakan metode quicksort.

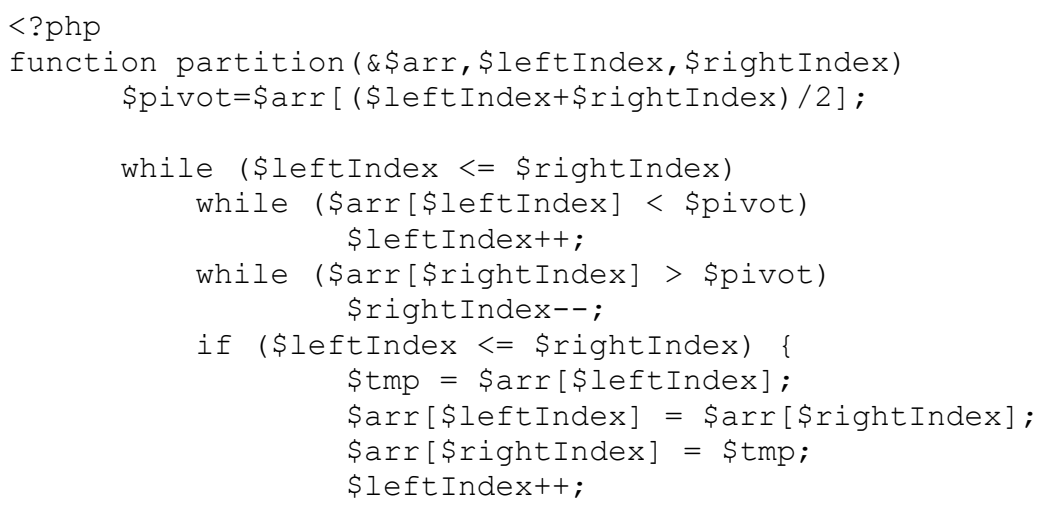




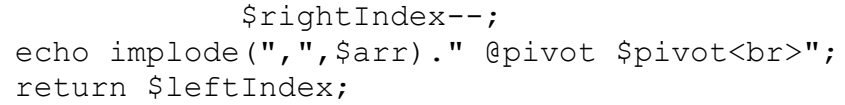

Berikut merupakan fungsi untuk mengurutkan data-data pertanyaan setelah diperoleh pivot.

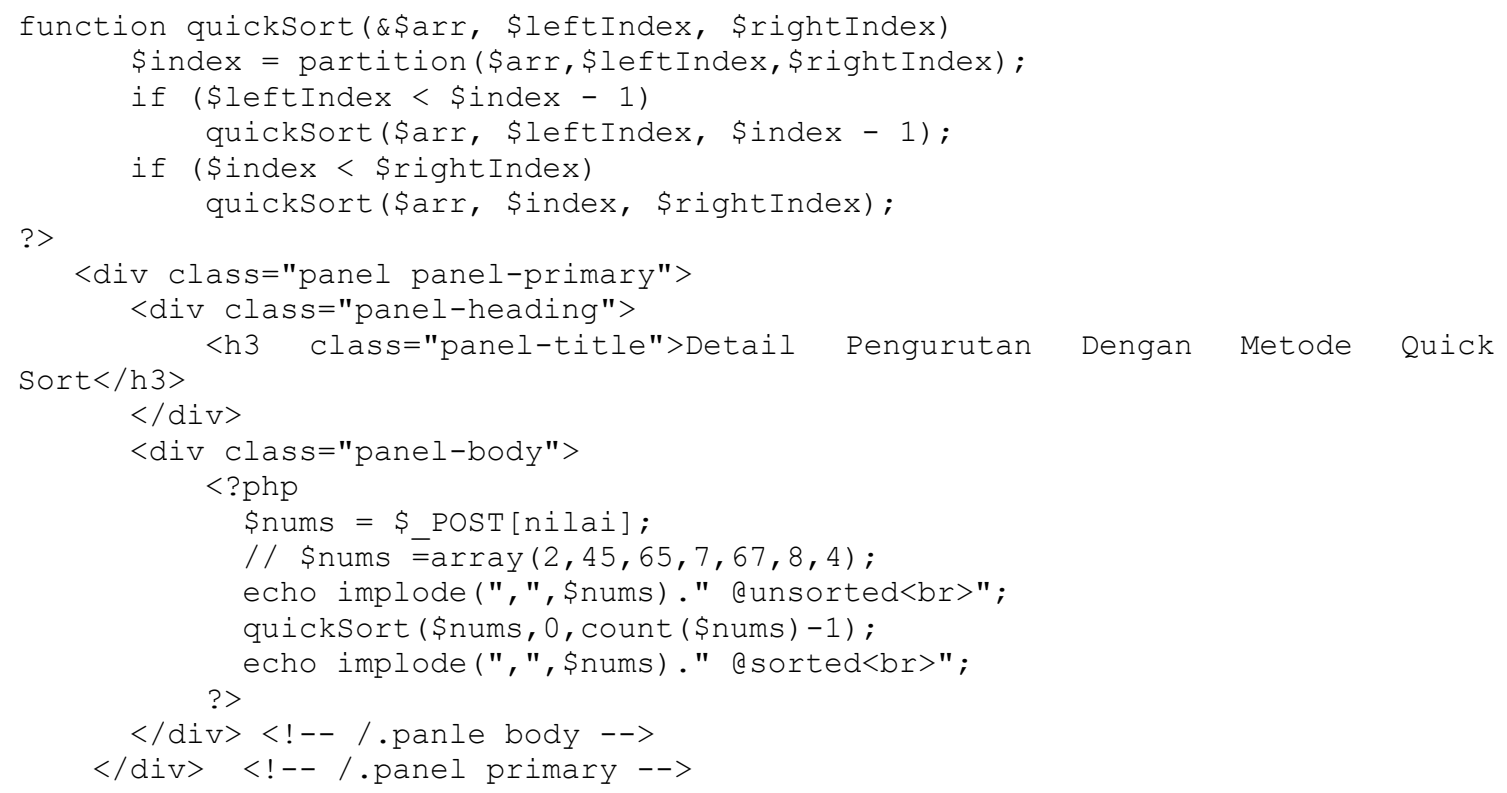

Tabel 1. Rekapitulasi hasil nilai rata-ratan keseluruhan pertanyaan per kategori variable menggunakan metode quicksort

\begin{tabular}{lc}
\hline \multicolumn{1}{c}{ Variabel } & Rata-rata \\
\hline Usability & 2.9 \\
Content & 2.6 \\
Pleasure & 2.5 \\
Classic Aesthetics & 2.7 \\
Expressive Aesthetics & 2.4 \\
Quality of Information & 2.7 \\
\hline
\end{tabular}

Tabel 1. merupakan rekapitulasi hasil nilai rata-rata keseluruhan pertanyaan perkategori variabel dari proses pengurutan berdasarkan metode quicksort. Pada tabel 1 bahwa nilai variabel Usability mempunyai nilai tertinggi yaitu dengan nilai rata-rata 2.9. Selanjutnya variabel Classic Aesthetics dan Quality of Information dengan nilai rata-rata 2.7 , kemudian variabel Content dengan nilai rata-rata 2.6 , variabel Pleasure dengan nilai rata-rata 2.5 serta variabel Expressive Aesthetics dengan nilai rata-rata 2.4. 
Tabel 2. Perbandingan Hasil Rekapitulasi Nilai Rata-Rata Dengan Aplikasi Statistik Dan Dengan Menggunakan Metode Quicksort.

\begin{tabular}{lcc}
\hline \multicolumn{1}{c}{ Variabel } & $\begin{array}{c}\text { Nilai rata-rata } \\
\text { hasil aplikasi Statistik }\end{array}$ & $\begin{array}{c}\text { Nilai rata-rata } \\
\text { menggunakan metode } \\
\text { Quicksort }\end{array}$ \\
\hline Usability & $\mathbf{3 . 1}$ & $\mathbf{2 . 9}$ \\
Content & 2.8 & 2.6 \\
Pleasure & 2.7 & 2.5 \\
Classic Aesthetics & 2.9 & 2.7 \\
Expressive Aesthetics & 2.5 & 2.4 \\
Quality of Information & 3.0 & 2.7 \\
\hline
\end{tabular}

Berdasarkan hasil pengolahan data menggunakan metode quicksort, nilai rata-rata yang diperoleh pada tabel 1 dan hasil nilai rata-rata pada tabel 2 dari penelitian sebelumnya yaitu penelitian [6] menjelaskan bahwa website STTA merupakan website yang Usability dengan kriteria "baik". Pengertian Usability menurut [7] bahwa usability adalah ukuran kemudahan suatu sistem untuk dapat dipelajari dan digunakan, efektif serta efisien sehingga sikap user menyukai dan puas dengan sistem tersebut. Sedangkan menurut [1], prinsip-prinsip untuk mendukung kegunaan (usability) yaitu:

a. Mudah dipelajari (Learnbility) yaitu kemudahan pengguna baru dapat menggunakan sistem secara efektif.

b. Keluwesan (Flexibility) yaitu banyaknya (berbagai) cara pengguna memperoleh atau menukar sistem informasi.

c. Kehandalan (Robustness) yaitu tingkat dukungan yang diberikan sistem ke user dalam menentukan keberhasilan pencapaian dan penilaian perilaku yang diarahkan sesuai tujuan user.

d. Hal tersebut mengindikasikan bahwa tujuan Human Computer Interaction (HCI) yaitu Usability, Effective dan Efficient masuk kriteria baik. Tetapi dari segi Appeal masuk kategori cukup, sehingga masih perlu dilakukan evaluasi guna perbaikan dan peningkatan website yang sudah ada.

\section{KESIMPULAN}

Setelah dilakukan pengolahan data dan menganalisa serta menguji data-data kuisioner, maka dapat disimpulkan beberapa hal sebagai berikut:

a. Pengujian penggunaan Website STTA dalam penelitian ini menggunakan metode quicksort mendapatkan hasil uji Usability, Quality of Information (kualitas informasi) dan Classic Aesthetics yang "baik", serta memiliki Content, Pleasure, Expressive Aesthetics yang "cukup".

b. Perlu dilakukan evaluasi dan tindak lanjut pada website STTA dalam hal Content, Pleasure, dan Expressive Aesthetics agar memenuhi harapan pengguna/pengunjung dari sisi user interface dan dapat memenuhi sebagian tujuan dari Human Computer Interaction (HCI) yaitu sisi appeal dan utility.

\section{DAFTAR PUSTAKA}

[1] Dix A; Finlay J,et al. 2004. Human-Computer Interaction, Prentice Hall.

[2] De Troyer. 2004. Human-Computer Interaction/User Interface. Chapter-. ppt.

[3] Hartami Santi, Indyah (2015) tentang "Tinjauan Human Computer Interaction (Hci) Terhadap Aplikasi Penjadwalan Sekolah “.https://ojs.amikom.ac.id. Vol 3, No 1.

[4] Insap Santosa, 2000, Struktur Data Menggunakan Turbo Pascal 6.0, Andi Offset Yogyakarta.

[5] Jogiyanto HM, MBA, Akt.,Ph.D. 2003. "Sistem Teknologi Informasi”, Penerbit ANDI, Yogyakarta.

[6] Nugraheny, Dwi. 2016. "Analisis User Interface dan User Experience pada Website Sekolah Tinggi Teknologi Adisutjipto (STTA) Yogyakarta “. Prosiding Seminar Nasional Teknologi Informasi dan Kedirgantaraan, hal. 183.

[7] Preece J, Rogers Y, Sharp H, et al. 1994. "Human-Computer Interaction”, Wokingham, UK: Addison-Wesley.

[8] Pujiatiningsih, Endang. 2004. “Analisis Perbandingan Algoritma Metode Pengurutan Quicksort, Metode Pengurutan Selectionsort Dan Metode Pengurutan Heapsort”. https://repository.unikom.ac. 
Jurnal SIMETRIS, Vol. 9 No. 1 April 2018

ISSN: 2252-4983

[9] Tata Sutabri. 2004. “Analisa Sistem Informasi. Hal:33. Penerbit: ANDI, Yogyakarta. 